ISSN 0258-7122 (Print), 2408-8293 (Online)

Bangladesh J. Agril. Res. 43(1): 53-69, March 2018

\title{
EFFECT OF UREA SUPER GRANULE AND PRILLED UREA ON THE GROWTH AND YIELD OF BROCCOLI
}

\author{
M. J. HUSSAIN ${ }^{1}$, A. J. M. S. KARIM ${ }^{2}$, A. R. M. SOLAIMAN ${ }^{2}$ \\ M. S. ISLAM ${ }^{2}$ AND M. RAHMAN ${ }^{3}$
}

\begin{abstract}
A field experiment was conducted at Bangabandhu Sheikh Mujibur Rahman Agricultural University, Gazipur during the period from 2012-13 to verify the effectiveness of urea super granule (USG) and prilled urea (PU)on growth, yield and yield attributes of broccoli in Shallow Red-Brown Terrace Soil under Madhupur Tract (AEZ-28). The experiment was laid out in a Randomized Complete Block Design with three replications having 5 treatments constituted with different levels of USG and PU as- $\mathrm{T}_{1}$ : Control, $\mathrm{T}_{2}$ : USG-N $\mathrm{N}_{140}(140 \mathrm{~kg} \mathrm{~N}$ as USG), $\mathrm{T}_{3}$ : USG-N $\mathrm{N}_{160}$ (160 kg N as USG), $\mathrm{T}_{4}$ : USG-N $\mathrm{N}_{180}(180 \mathrm{~kg} \mathrm{~N}$ as USG), $\mathrm{T}_{5}$ : PU-N ${ }_{180}(180 \mathrm{~kg} \mathrm{~N}$ as PU). Performance of USG was better than PU and the treatment USG-N $\mathrm{N}_{160}$ gave the highest yield (13.49 ton $\left.\mathrm{ha}^{-1}\right)$ which was followed by USG-N ${ }_{180}\left(12.43\right.$ ton $\left.\mathrm{ha}^{-1}\right)$ and $\mathrm{PU}-\mathrm{N}_{180}\left(12.05\right.$ ton ha- $\left.{ }^{-1}\right)$ having significant difference among these. Higher but statistically identical number of lateral head 5.103 and 5.38 was produced by USG-N ${ }_{160}$ and USG-N ${ }_{180}$ treatments, respectively in comparison with PU-N $\mathrm{N}_{180}$ (5.04). But higher lateral head yields (6.05 and 5.03 ton $\mathrm{ha}^{-1}$ ) were found in USG-N $\mathrm{N}_{180}$ treatments followed by PU$\mathrm{N}_{180}$. All the yield contributing characters and the economic profitability were favorably correlated with these high yield performing treatments with the highest MRR (3336.67\%) obtained from USG-N $\mathrm{N}_{160}$ which indicated that USG @ $160 \mathrm{~kg} \mathrm{~N} \mathrm{ha}^{-1}$ (USG-N $\mathrm{N}_{160}$ ) is the most economically viable $\mathrm{N}$ dose in terms of yield and economics for broccoli production. Therefore, USG @ $160 \mathrm{~kg} \mathrm{~N} \mathrm{ha}{ }^{-1}$ (USG-N ${ }_{160}$ ) with other recommended fertilizer could be suggested as USG based fertilizer recommendation for better broccoli production in terms of yield and economics in Silty Clay Loam Soil of Madhupur Tract.
\end{abstract}

Keywords: Broccoli, USG, head yield, lateral head, compactness coefficient, economic evaluation

\section{Introduction}

Broccoli (Brassica oleracia var italica L.) is one of the winter vegetables belonging to the family Cruciferae and it is a beneficial and more nutritious vegetable than any other of the same genus (Yoldas et al., 2008). It is well known that, broccoli has enormous nutritional and medicinal values due to its

${ }^{1}$ Senior Scientific Officer, Soil \& Water Management Section, Horticulture Research Centre, Bangladesh Agricultural Research Institute (BARI), Gazipur, ${ }^{2}$ Professor, Department of Soil Science, Bangabandhu Sheikh Mujibur Rahman Agricultural University (BSMRAU), Gazipur, ${ }^{3}$ Professor, Department of Hoticulture, BSMRAU, Gazipur, Bangladesh. 
high contents of vitamins ( $\mathrm{A}, \mathrm{B}_{1}, \mathrm{~B}_{2}, \mathrm{~B}_{5}, \mathrm{~B}_{6}$ and $\mathrm{E}$ ), minerals $(\mathrm{Ca}, \mathrm{Mg}, \mathrm{Zn}$ and $\mathrm{Fe}$ ) and antioxidant substances which prevent the formation of cancer causing agents. Broccoli contains a higher rate of sulforaphane that prevents against bacteria Helicobacter pylori which are responsible for stomach cancer (Fahey et al., 2002). Nitrogen plays an important role in broccoli production and broccoli is highly dependent on $\mathrm{N}$ fertilization to achieve a good yield (Babik \& Elkner 2002). The total yield of broccoli is greatly influenced by different doses of nitrogenous fertilizer. The farmers of Bangladesh usually use PU for cultivation of crops. At present, different types of $\mathrm{N}$ fertilizer materials are available in the market to improve fertilizer use efficiency. Among those USG is used by the farmers in some parts of the country for upland vegetable crops like tomato, cabbage, broccoli, papaya, banana etc (Hussain et al., 2003; Nazrul et al., 2006). High yielding and high quality broccoli production requires careful nutrient management (Castellanos et al., 1999). Zaman et al. (1993) reported that $\mathrm{N}$ is an important plant nutrient and is the most limiting one due to its high mobility and different types of losses. To control this type of losses, USG application may be a good option to minimize production cost as well as to increase $\mathrm{N}$ use efficiency, yield and quality of the crop. As nitrogen plays a major role in agricultural production and is also responsible for a number of environmental problems $\mathrm{N}$ management is indispensable for maximizing broccoli yield and minimizing cost of production which may lead to increase farmer's income. Therefore it is essential to evaluate the effect of different forms and levels of urea as USG and PU application for sustainable crop production. To attain this goal the present study was undertaken to verify the effectiveness of USG and PU on crop growth, yield and yield attributes of broccoli; to assess the comparative performance of USG and PU on lateral head production of broccoli, to assess the economic performance of broccoli with USG and PU application and to develop an USG based fertilizer recommendation as compare to PU for broccoli production.

\section{Materials and Methods}

The field experiment was conducted at the research field and the analytical part of the experiments were done at the laboratory of the Department of Soil Science, Bangabandhu Sheikh Mujibur Rahman Agricultural University during the period from 2012 to 2013 with a view to verifying the effectiveness of USG and PU on yield and quality of broccoli, to assess the comparative performance of USG and PU on nutrient uptake and uptake efficiency of broccoli, to evaluate the effect of USG and PU on post harvest soil nutrient status of broccoli field and to develop an USG based fertilizer recommendation as compared to PU with maximum yield and economic profitability. The soil of the experimental field belongs to Salna series representing the Shallow Red Brown Terrace soil in Bangladesh soil classification system, which falls under order Inceptisols in Soil Taxonomy 
(FAO, 1988). The soil of the study area is silty clay loam in texture having bulk density $1.34 \mathrm{~g} \mathrm{~cm}^{-3}$ and particle density $2.61 \%$, porosity $47.47 \%$ and soil moisture at field capacity $28.67 \%$. Chemical properties of soilwere analyzed in the BSMRAU laboratory of the Department of Soil Science and the results obtained were presented in Table 1.

Table 1. Chemical properties of the initial soil of the experimental plot

\begin{tabular}{|c|c|c|c|c|c|c|c|c|}
\hline \multirow{2}{*}{$\begin{array}{l}\text { Soil properties } \\
\text { (0-15 cm soil } \\
\text { depth) }\end{array}$} & \multirow{2}{*}{$\begin{array}{c}\text { Soil } \\
\mathrm{pH}\end{array}$} & $\begin{array}{c}\text { Organic } \\
\text { carbon }\end{array}$ & $\begin{array}{c}\text { Total } \\
\mathrm{N}\end{array}$ & $\begin{array}{c}\text { Exchangeable } \\
\mathrm{K}\end{array}$ & CEC & $\begin{array}{c}\text { Available } \\
\mathrm{P}\end{array}$ & $\begin{array}{c}\text { Available } \\
\text { S }\end{array}$ & $\begin{array}{c}\text { Available } \\
\text { B }\end{array}$ \\
\hline & & \multicolumn{2}{|l|}{$\%$} & \multicolumn{2}{|c|}{ meq/100g soil } & \multicolumn{3}{|c|}{$\mu \mathrm{g} \mathrm{g}^{-1}$} \\
\hline $\begin{array}{l}\text { Analytical } \\
\text { alue }\end{array}$ & 5.97 & 0.96 & 0.10 & 0.32 & 12.67 & 14.18 & 13.78 & 0.21 \\
\hline
\end{tabular}

The experiment was laid out in a Randomized Complete Block Design (RCBD) with three replications having 5 treatments comprising different levels of $\mathrm{N}$ in the form of USG and PU.The treatments are- $\mathrm{T}_{1}: 0 \mathrm{~kg} \mathrm{~N}$ (Control), $\mathrm{T}_{2}: 140 \mathrm{~kg} \mathrm{~N}$ as USG (USG- $\left.\mathrm{N}_{140}\right), \mathrm{T}_{3}: 160 \mathrm{~kg} \mathrm{~N}$ as USG $\left(\mathrm{USG} \mathrm{N}_{160}\right), \mathrm{T}_{4}: 180 \mathrm{~kg} \mathrm{~N}$ as USG (USG- $\mathrm{N}_{180}$ ) and $\mathrm{T}_{5}: 180 \mathrm{~kg} \mathrm{~N}$ as PU (PU-N ${ }_{180}$ ). Besides these a blanket dose of $\mathrm{P}$, $\mathrm{K}, \mathrm{S}, \mathrm{Zn}, \mathrm{B}$, and Mo were applied for all treatments @ $53 \mathrm{~kg} \mathrm{P}, 83 \mathrm{~kg} \mathrm{~K}, 20 \mathrm{~kg} \mathrm{~S}$, $2.0 \mathrm{~kg} \mathrm{Zn}, 1 \mathrm{~kg} \mathrm{~B}$ and $0.8 \mathrm{~kg} \mathrm{Mo} \mathrm{ha}^{-1}$. Nitrogen,P, K, S, Zn, B, and Mo were applied in the form of USG, and PU, TSP, MoP, gypsum, boric acid, zinc oxide and sodium molybdate. The treatments were randomly assigned to each block. "Premium Crop" a high yielding variety of broccoli (Brassica oleracea var. Italica L.) collected from Taki seed company, Japan was used as a test crop in the experiment. The unit plot size was $2.4 \mathrm{~m} \times 2.7 \mathrm{~m}\left(6.48 \mathrm{~m}^{2}\right)$ having plot to plot and block to block distances $0.75 \mathrm{~m}$ and $1.0 \mathrm{~m}$, respectively. After proper land preparation, 25-day-old healthy broccoli seedlings were transplanted in lines on November 20, 2012 maintaining a row to row and plant to plant distance of $0.60 \mathrm{~m}$ and $0.45 \mathrm{~m}$, respectively. Each plot was watered uniformly at every alternate day by watering can to bring the soil moisture at desired level and establishment of the crop. Weeding was done twice just before at first and second top dressing. Earthing up was done to make a continuous line of ridges and furrows. After stand establishment, furrow irrigation was given at an interval of 7 days. All the fertilizers with 50\% MoP except PU and USG were applied as broadcast and incorporated during final land preparation. Prilled urea was topdressed in two equal splits at 15 and 35 DAT as ring method round the plant mixing with the soil properly. At 15 DAT USG was placed at $7-8 \mathrm{~cm}$ below the surface and 9-10 cm apart from plant base. The rest 50\% MoP was also top-topdressed at 15 DAT followed by irrigation (depending on soil moisture status). Harvesting was started on $25^{\text {th }}$ January and continued up to $5^{\text {th }}$ February, 2013. Data on total weight, root weight, number of leaves per plant; head weight and other parameters and plant samples were recorded soon after harvesting. The 
crop was harvested when the head or inflorescence was at commercial maturity, just started to swell but before opening the flower bud. The entire plants including the head and roots were harvested very carefully with the help of a shovel and necessary data were recorded soon after harvesting. Before harvesting head diameter and after harvesting head length was measured using a centi-meter scale. The weight of individual head was taken including the stalk with three young leaves of the broccoli plant and the marketable portion of the plant was considered to the extent of about $15 \mathrm{~cm}$ from the top of the inflorescence along the stem according to Liu et al. (1993). The collected data were compiled and tabulated in proper form and statistical analysis was done by using the statistical package MSTATC. Computation and preparation of graphs were made using Microsoft Excel 2003 program. Economic evaluation of different fertilizer combinations was done through partial budgeting followed by marginal analysis of the cost-benefit as suggested by Perrin et al. (1979).

Initial soil samples were collected for analysis of both physical and chemical properties of soil. Plant height and number of leaves plant ${ }^{-1}$ were noted at 10 days interval and economic data were recorded for economic analysis and evaluation.

Compactness coefficient (CC) an indicator of the quality of a head was observed. Head compactness coefficient is the ratio of head yield $\left(\mathrm{g}\right.$ plant $\left.{ }^{-1}\right)$ to head diameter $(\mathrm{cm})$ was estimated by the formula:

Compactness coefficient $(\mathrm{CC})=\frac{\text { Head yield }\left(\mathrm{g} \mathrm{plant}^{-1}\right)}{\text { Head diameter }(\mathrm{cm})}$

Plant biomass was estimated by oven drying the plant samples at $65^{\circ}-70^{\circ} \mathrm{C}$ for 72 hours and weighing. The biomass per plant, biomass per plot and biomass per hectare were calculated by the following formulae:

a). Biomass per plant $(\mathrm{g})=\frac{\text { Total above ground biological yield of } 10 \text { plants }(\mathrm{g})}{10}$

b). Biomass per hectare $(\mathrm{kg})=$ Biomass yield per plant $(\mathrm{kg}) \times$ Number of plants ha ${ }^{-1}$

Economic evaluation of different fertilizer combinations was done through partial budgeting and dominance analysis followed by marginal analysis of the cost undominated treatments was also done as suggested by Perrin et al.(1979). Gross return and variable costs were calculated considering the following price rate of the materials as- Input cost: Prilled urea @ Tk. $12.00 \mathrm{~kg}^{-1}$, USG @ Tk. $12.30 \mathrm{~kg}^{-1}$, TSP @ Tk. $22 \mathrm{~kg}^{-1}$, MP @ Tk. $20 \mathrm{~kg}^{-1}$, Gypsum @ Tk. $7 \mathrm{~kg}^{-1}$, Zinc monohydrate@Tk.18 kg-1, Borax @ Tk.15 kg-1 Cow dung@ Tk.1500 ton ${ }^{-1}$, Poultry manure@Tk.2000 ton ${ }^{-1}$, Mustard oil cake @ Tk. $28 \mathrm{~kg}^{-1}$ (according to market rate during the year 2012-13). Fertilizer application and placement cost were considered as a variable cost which was estimated through labor 
requirement $\mathrm{ha}^{-1}$ according to treatments. These are: 56.58 labor ha ${ }^{-1}$ ( 2 times application) common for all the PU treatment; 27.86 labor for $80 \mathrm{~kg}$; 30 labor for $100 \mathrm{~kg}, 2.29$ labor for $120 \mathrm{~kg}, 34.29$ labor for $140 \mathrm{~kg}, 39.86$ labor for $160 \mathrm{~kg}$, 41.58 labor for $180 \mathrm{~kg}, 49.29$ labor for $200 \mathrm{~kg}$ and 54.01 labor for $220 \mathrm{~kg}$ USG treatment ha ${ }^{-1}$. Labor cost=Tk.180 diam ${ }^{-1}$. Output cost: Broccoli= @ Tk. $30 \mathrm{~kg}^{-1}$ (according to market rate during the year 2012-2013).

Benefit cost ratio (BCR), marginal benefit cost ratio (MBCR) and marginal rate of return (MRR) were calculated using the following formula:

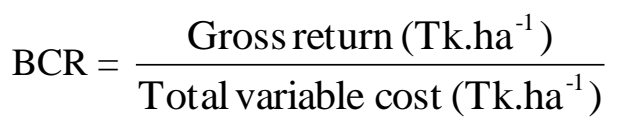

MBCR $=\frac{\text { Added return }\left(\mathrm{Tk} \cdot \mathrm{ha}^{-1}\right)}{\text { Added cost of cultivation }\left(\mathrm{Tk}^{-1} \mathrm{ha}^{-1}\right)}$

$\operatorname{MRR}(\%)=\frac{\text { Marginal gross margin }\left(\mathrm{Tk}^{\mathrm{h}} \mathrm{ha}^{-1}\right)}{\text { Marginal variable cost }\left(\mathrm{Tk}_{\mathrm{h}} \mathrm{ha}^{-1}\right)}$

\section{Results and Discussion}

\section{Plant height}

From Fig.1 it was found that plant height was significantly influenced by the different forms and levels of urea and it was increased with increasing rate of $\mathrm{N}$ fertilizer and the higher plant height was observed in PU-N $\mathrm{N}_{180}$ at initial stage from 10 to 20 DAT but in the later stages from 30-70 DAT the highest plant height was observed in the highest level of USG (USG-N 180 ). Growth pattern in relation to plant height at different DAT affected by different forms and levels of urea $\mathrm{N}$ is shown in Fig.1 and it is observed that plant height was increased rapidly in intermediate stage and maximum height was attained within 60 DAT and then it maintained a plateau. It reveals that higher plant height was achieved from USG treated plots as compared to that of PU. At harvesting the highest plant height $(67.10 \mathrm{~cm})$ was recorded from USG-N ${ }_{180}$ which was statistically identical with USG-N ${ }_{160}(65.28 \mathrm{~cm})$ and $\mathrm{PU}-\mathrm{N}_{180}(64.77 \mathrm{~cm})$ (Fig.1). This phenomenon might be due to continuous supply, higher availability and uptake rate of $\mathrm{N}$ from USG for long time than that of PU. The minimum plant height $(44.98 \mathrm{~cm})$ was recorded from control. These results are similar to the findings of Hala and Nadia (2009) as they showed that different mineral fertilizers significantly influenced broccoli growth characters and the highest plant height and number of leaves plant ${ }^{-1}$ were recorded by the plants with maximum $\mathrm{N}$ fertilizer along with $\mathrm{P}$ and $\mathrm{K}$. 


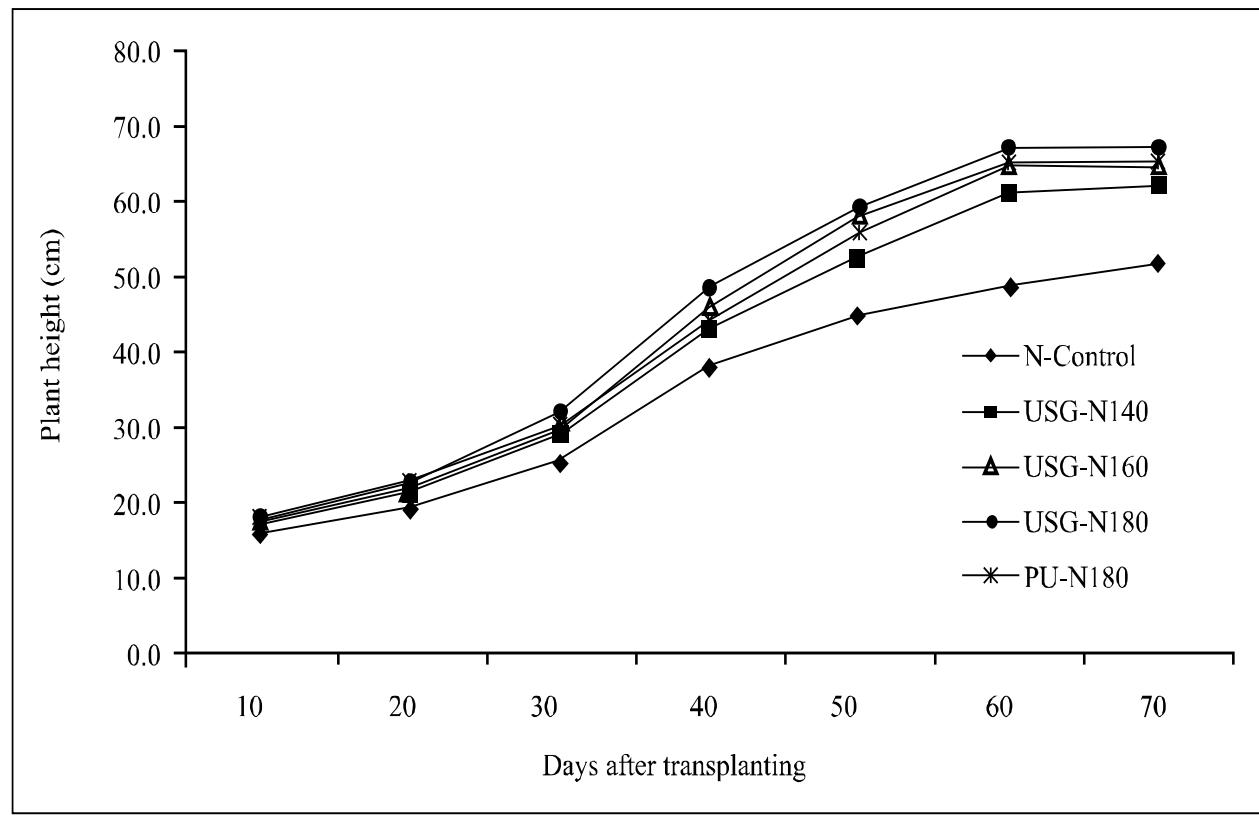

Fig. 1. Growth pattern of broccoli as affected by different levels of USG and PU in relation to plant height.

\section{Number of leaves plant ${ }^{-1}$}

At initial stage up to 20 days after transplanting (DAT), no significant influence was observed in different forms and levels of urea $\mathrm{N}$ but in the later stages from 30 DAT, it was significantly affected by different levels of $\mathrm{N}$ treatment (Fig.2). Growth pattern in relation to number of leaves plant ${ }^{-1}$ at different DAT was affected by different forms and levels of urea $\mathrm{N}$ which was shown in Fig. 3 and observed that the number of leaves plant ${ }^{-1}$ rapidly increased in intermediate stage and the maximum number of leaves plant $^{-1}$ was recorded within 60 DAT but a little or no change was observed in the later stages upto harvesting. At harvest(70 DAT), the number of leaves was significantly affected by fertilizer treatments and the maximum number (14.30 plant $\left.^{-1}\right)$ was recorded from the treatment USG-N ${ }_{180}$ followed by USG- $\mathrm{N}_{160} \mathrm{~kg} \mathrm{~N} \mathrm{Na}^{-1}$ having the number 14.10 (Fig.2). The minimum number of leaves (11.63) was obtained from the control. These results are in accordance with the findings of Ouda and Mahadeen (2008) in broccoli. Thakur et al. (1991) reported that increasing rate of $\mathrm{N}$ application delayed head maturity and increased the number of leaves plant ${ }^{-1}$, leaf area, gross plant weight, stalk length, dry matter content and head yield of cauliflower. 


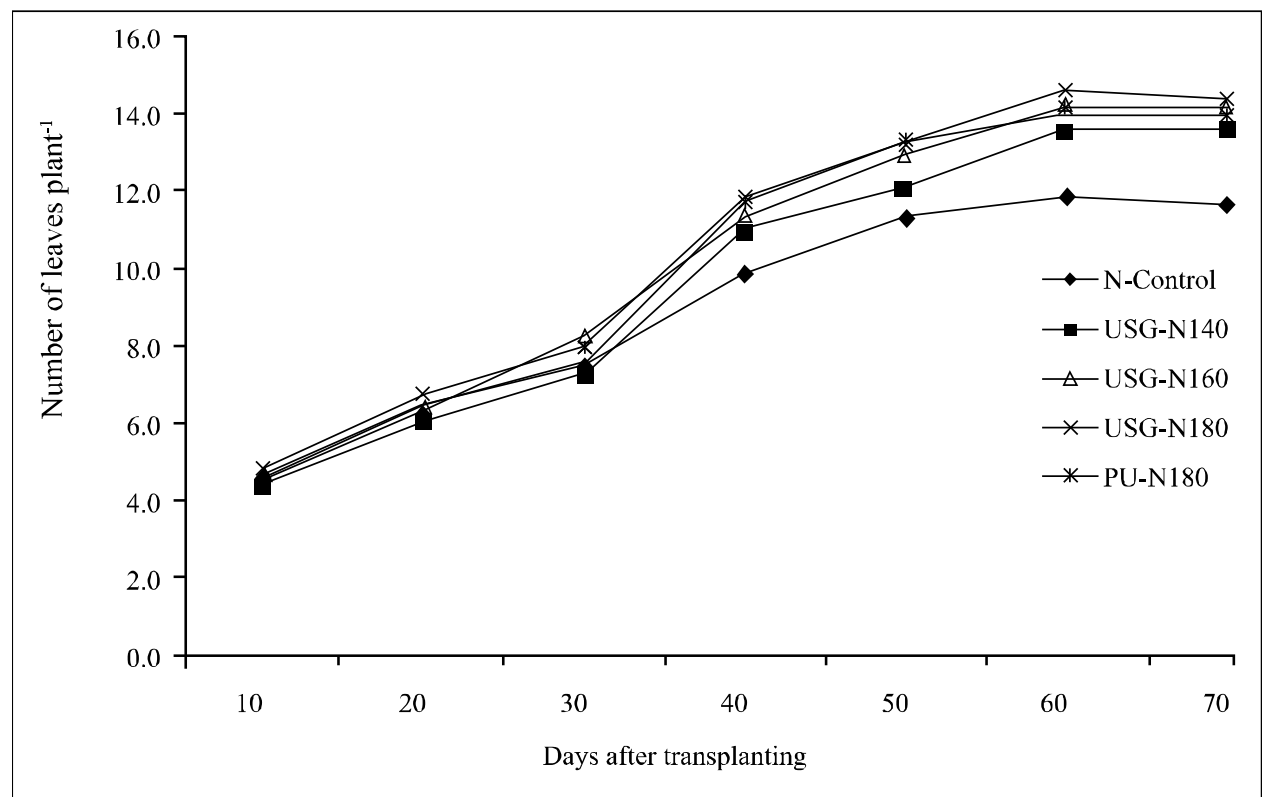

Fig. 2. Growth pattern of broccoli as affected by different levels of USG and PU in relation to number of leaves plant ${ }^{-1}$.

\section{Days to head initiation}

No significant difference was observed among the treatment levels both for $1^{\text {st }}$ and $50 \%$ head initiation although the higher days were required in higher rate of $\mathrm{N}$ application and also from control (Table 2). The maximum days to first head initiation (47.67 days) was recorded from control followed by USG$\mathrm{N}_{180}$ (46.67 days). Similarly, the maximum days to 50\% head initiation (50.00 days) was required in control plot followed by USG-N $\mathrm{N}_{180}$ (49.00 days). This might be due to higher vegetative growth induced by the higher uptake rate of $\mathrm{N}$ by the crop with a sufficient and continuous supply of $\mathrm{N}$ by the USG that hindering the head initiation. The higher time required for head initiation from control plot due to lack of optimum development and carbohydrate assimilation which is essential for head initiation. The USG treated plots took more time to $50 \%$ head initiation as because of continuous and higher supply of $\mathrm{N}$, which induces higher vegetative growth and consequently delayed head initiation. This finding supported the findings of Default (1988) as reported that increasing $\mathrm{N}$ rates decreased the days to heading and harvest in greenhouse broccoli. Thakur et al. (1991) found that the increasing rate of $\mathrm{N}$ delayed head maturity of cauliflower. Similar findings were reported by Balyan et al. (1988) in cauliflower. 
Table 2. Effect of different levels of USG and PU on head initiation of broccoli

\begin{tabular}{|c|c|c|}
\hline Treatment & $1^{\text {st }} \mathrm{HI}$ (DAT) & $50 \% \mathrm{HI}(\mathrm{DAT})$ \\
\hline Control & 47.67 & 50.00 \\
\hline USG-N 140 & 46.33 & 47.33 \\
\hline USG-N 160 & 46.33 & 48.67 \\
\hline USG-N 180 & 46.67 & 49.00 \\
\hline PU-N 180 & 46.33 & 48.67 \\
\hline $\mathrm{CV}(\%)$ & 1.92 & 5.33 \\
\hline $\mathrm{SE}( \pm 0.05)$ & $0.5164 \mathrm{~ns}$ & $1.487 \mathrm{~ns}$ \\
\hline
\end{tabular}

Means followed by uncommon letters are statistically different from each other at $5 \%$ level of provability by DMRT

HI: Head initiation; DAT: Days after transplanting

\section{Fresh root weight}

Fresh root weight was also significantly influenced by the different levels of urea and the highest fresh root weight (43.83 $\mathrm{g} \mathrm{plant}^{-1}$ ) was found from USG-N $\mathrm{N}_{160}$ followed by USG-N $\mathrm{N}_{180}$ which was statistically identical with PU-N $\mathrm{N}_{180}$ and USG$\mathrm{N}_{140}$ (Table 3). This might be due to higher root expansion with lower availability of $\mathrm{N}$ in comparison to USG- $\mathrm{N}_{180}$. The minimum root weight (34.41 $\left.\mathrm{g} \mathrm{plant}^{-1}\right)$ was recorded from $\mathrm{N}$-control.

\section{Fresh shoot weight}

Fresh shoot weight was also significantly influenced by the different levels of urea and the highest fresh shoot weight (1495.0 $\left.\mathrm{g}_{\text {plant }}{ }^{-1}\right)$ was found from USG$\mathrm{N}_{180}$ followed by USG-N $\mathrm{N}_{160}$ which was statistically identical with PU-N $\mathrm{N}_{180}$ and USG-N $\mathrm{N}_{140}$ (Table 3). This higher shoot weight might be due to higher carbohydrate accumulation with higher availability and uptake of $\mathrm{N}$. The minimum shoot weight (543.6 $\left.\mathrm{g} \mathrm{plant}^{-1}\right)$ was recorded from $\mathrm{N}$-control plot. Zebarth et al. (1995) found that total aboveground dry matter increased linear to curvilinearly with increasing rate of $\mathrm{N}$ application in broccoli planting. This result is in accordance with the findings of Thakur et al. (1991) in cauliflower.

\section{Root dry weight}

Dry root weight was also significantly influenced by the different levels of urea and the highest root dry weight (10.92 $\left.\mathrm{g} \mathrm{plant}^{-1}\right)$ was recorded from USG-N ${ }_{160}$ followed by USG-N 180 which was statistically identical with PU-N ${ }_{180}$ and USG$\mathrm{N}_{140}$ (Table 3). This might be due to higher root expansion with lower availability of nitrogen in comparison to USG-N $\mathrm{N}_{180}$. The minimum root weight $\left(8.57 \mathrm{~g} \mathrm{plant}^{-}\right.$ 1) was found from N-control. 


\section{Shoot dry weight}

Shoot dry weight was also affected significantly by the different levels of nitrogen fertilizer. It was observed that shoot dry weight increased with increasing level of $\mathrm{N}$ and the highest shoot dry weight (192.9 $\left.\mathrm{g} \mathrm{plant}^{-1}\right)$ was recorded from USG-N $\mathrm{N}_{160}$ followed by USG- $\mathrm{N}_{180}$ which was statistically identical with PU-N $\mathrm{N}_{180}$ and USG-N $\mathrm{N}_{140}$ (Table 3). This might be due to higher water content in fresh shoot obtained from USG- $\mathrm{N}_{180}$. The minimum shoot dry weight was found in N-control.

Table 3. Effect of different levels of USG and PU on fresh and dry weight of different growth parameters of broccoli

\begin{tabular}{l|c|c|c|c}
\hline Treatment & $\begin{array}{c}\text { Fresh root } \\
\text { weight } \\
\left(\text { g plant }^{-1}\right)\end{array}$ & $\begin{array}{c}\text { Fresh shoot } \\
\text { weight } \\
\left(\text { g plant }^{-1}\right)\end{array}$ & $\begin{array}{c}\text { Root dry weight } \\
\left(\text { g plant }^{-1}\right)\end{array}$ & $\begin{array}{c}\text { Shoot dry weight } \\
\left(\text { g plant }^{-1}\right)\end{array}$ \\
\hline Control & $34.41 \mathrm{~b}$ & $543.6 \mathrm{~b}$ & $8.57 \mathrm{~b}$ & $86.84 \mathrm{~b}$ \\
USG-N $_{140}$ & $41.51 \mathrm{a}$ & $1363.0 \mathrm{a}$ & $10.33 \mathrm{a}$ & $175.8 \mathrm{a}$ \\
USG-N $_{160}$ & $43.83 \mathrm{a}$ & $1404.0 \mathrm{a}$ & $10.92 \mathrm{a}$ & $192.9 \mathrm{a}$ \\
USG-N $_{180}$ & $43.67 \mathrm{a}$ & $1495.0 \mathrm{a}$ & $10.87 \mathrm{a}$ & $181.1 \mathrm{a}$ \\
PU-N & $42.87 \mathrm{a}$ & $1392.0 \mathrm{a}$ & $10.68 \mathrm{a}$ & $179.5 \mathrm{a}$ \\
\hline CV $(\%)$ & 7.33 & 5.57 & 7.34 & 5.51 \\
SE $( \pm 0.05)$ & 1.746 & 39.85 & 0.4351 & 5.194 \\
\hline
\end{tabular}

Means followed by uncommon letters are statistically different from each other at $5 \%$ level of provability by DMRT

\section{Head length}

Head length was significantly influenced by the different levels of $\mathrm{N}$ fertilizer. It was decreased with increasing level of $\mathrm{N}$ up to USG-N ${ }_{180}$ (Table 4). The highest head length $(14.07 \mathrm{~cm})$ was recorded from USG-N ${ }_{140}$ followed by USG-N ${ }_{160}$ which was statistically identical with PU-N $\mathrm{N}_{180}$ and USG-N $\mathrm{N}_{180}$. The head length recorded in PU-N ${ }_{180}$ was higher than that of USG-N $\mathrm{N}_{180}$ which might be due to lower flow of translocation to cell development in comparison to cell elongation. The lowest head length was observed in $\mathrm{N}$-control. This result was also in harmony with that of the findings of Chao-Jiong et al. (2010) in broccoli.

\section{Head diameter}

Head diameter was significantly affected by the different levels of $\mathrm{N}$ and the maximum head diameter $(19.47 \mathrm{~cm})$ was recorded from $\mathrm{USG}_{160}$ treatment which was statistically similar to USG-N $\mathrm{N}_{180}(18.67 \mathrm{~cm})$ but significantly higher than all other treatments (Table 4). This might be due to continuous and balanced supply of assimilates from leaf to floret. The lowest diameter $(9.83 \mathrm{~cm})$ was recorded from control. This finding is in agreement with the findings of Yoldas et al. (2008) who reported that increased $\mathrm{N}$ rates significantly increased yield, average weight of main and lateral heads, and the diameter in broccoli compared to 
control. This result is also very close to the findings of Thompson and Kelly (1985), who reported that the diameter of cabbage head significantly increased with the optimum dose of $\mathrm{N}$.

\section{Head weight}

Individual head weight was significantly influenced by the application of different $\mathrm{N}$ levels. It was increased with increasing level of $\mathrm{N}$ fertilizer but the highest head weight (364.3 g plant $^{-1}$ ) was obtained from USG-N ${ }_{160}$ followed by USG-N ${ }_{180}$ which was statistically identical with $\mathrm{PU}_{180}$ (Table 4). This might be due to maximum translocation of carbohydrate from leaf to head which increased size, shape and head compactness with an optimum vegetative growth. The minimum head weight (131.8 g plant $\left.^{-1}\right)$ was obtained from control. The low crop yield from the control treatment is due to the insufficient supply of $\mathrm{N}$ in plants, leading to limit the carbon assimilation, resulting in reduction of plant productivity. This result was supported by the findings of Greenwood et al. (1980) who found the highest yield from recommended doses of $175-252 \mathrm{~kg} \mathrm{~N}$ ha $^{-1}$. Similar results were obtained by Chao-Jiong (2010) in broccoli. Rickard (2008) reported that $\mathrm{N}$ had a curvilinear effect on marketable yield and an increase was seen up to application of $165 \mathrm{~kg} \mathrm{~N} \mathrm{ha}^{-1}$ where the response is in plateau which also supported these findings.

\section{Compactness coefficient}

The higher the head compactness the better the head quality of broccoli. Head compactness were significantly increased with increasing levels of $\mathrm{N}$ and the highest compactness coefficient (18.91) was found from PU-N $\mathrm{N}_{180}$ followed by USG-N $\mathrm{N}_{160}$ (18.71) which were statistically similar to all the treatments except control that attained the lowest compactness coefficient (13.41)(Table 4). It was due to higher supply of translocates but lower cell elongation which might have caused maximum accumulation of assimilates as well as higher head compactness. This finding is in agreement with the result of Renata et al. (2005) in broccoli.

Table 4. Effect of different levels of USG and PU on different parameters of broccoli head

\begin{tabular}{l|c|c|c|c}
\hline Treatment & $\begin{array}{c}\text { Head length } \\
(\mathrm{cm})\end{array}$ & $\begin{array}{c}\text { Head diameter } \\
(\mathrm{cm})\end{array}$ & $\begin{array}{c}\text { Head weight } \\
\left(\mathrm{g} \mathrm{plant}^{-1}\right)\end{array}$ & $\begin{array}{c}\text { Compactness } \\
\text { coefficient }(\mathrm{CC})\end{array}$ \\
\hline Control & $10.40 \mathrm{~b}$ & $9.83 \mathrm{~d}$ & $131.8 \mathrm{c}$ & $13.41 \mathrm{~b}$ \\
USG-N $_{140}$ & $14.07 \mathrm{a}$ & $17.43 \mathrm{bc}$ & $316.3 \mathrm{~b}$ & $18.15 \mathrm{a}$ \\
USG-N $_{160}$ & $14.00 \mathrm{a}$ & $19.47 \mathrm{a}$ & $364.3 \mathrm{a}$ & $18.71 \mathrm{a}$ \\
USG-N $_{180}$ & $13.07 \mathrm{a}$ & $18.67 \mathrm{ab}$ & $349.0 \mathrm{ab}$ & $18.69 \mathrm{a}$ \\
PU-N & $13.47 \mathrm{a}$ & $17.20 \mathrm{c}$ & $325.3 \mathrm{ab}$ & $18.91 \mathrm{a}$ \\
\hline CV $(\%)$ & 8.58 & 4.04 & 6.88 & 7.53 \\
SE $( \pm 0.05)$ & 0.6439 & 0.3851 & 11.82 & 0.7622 \\
\hline
\end{tabular}

Means followed by uncommon letters are statistically different from each other at $5 \%$ level of provability by DMRT 


\section{Head dry weight}

The different levels of $\mathrm{N}$ application significantly influenced head dry weight. It was increased with increasing level of $\mathrm{N}$ fertilizer and the highest head dry weight $\left(60.12 \mathrm{~g} \mathrm{plant}^{-1}\right)$ was obtained from the treatment USG-N $\mathrm{N}_{160}$ followed by USG-N $\mathrm{N}_{180}$ which were statistically identical to PU-N $\mathrm{N}_{180}$ (Table 5). This might be due to maximum translocation of carbohydrate from leaf to head which increased size, shape and head compactness producing maximum dry matter. The minimum head dry weight $\left(21.74 \mathrm{~g}_{\text {plant }}{ }^{-1}\right)$ was obtained from control. Evaraarts et al. (1999) found that band placement of $\mathrm{N}$ positively influenced $\mathrm{N}$ uptake and this method of $\mathrm{N}$ application resulted in a higher head dry matter production.

\section{Harvest index}

Harvest index was calculated from head yield $\left(\mathrm{g}_{\text {plant }}{ }^{-1}\right)$ and fresh shoot yield $(\mathrm{g}$ plant $\left.^{-1}\right)$ and is presented in Table 5. The maximum harvest index $(25.95 \%)$ recorded from treatment USG-N $\mathrm{N}_{160}$ followed by $\mathrm{N}$-control. The PU-N 180 produced lower harvest index (23.37\%) than USG-N $\mathrm{N}_{160}$.

\section{Head yield}

The different $\mathrm{N}$ levels significantly influenced head yield of broccoli. It was increased with increasing level of $\mathrm{N}$ upto a certain level. The highest head yield (13.49 ton ha ${ }^{-1}$ ) was obtained from USG-N ${ }_{160}$ closely followed by USG$\mathrm{N}_{180}$ having no significant difference between these two treatments (Table 5). This might be due to maximum translocation of carbohydrate from leaf to head which increased size and head compactness optimizing vegetative growth. The minimum head yield (4.88 ton ha-1) was noted from the control. The treatment USG- $\mathrm{N}_{160}$ produced $276.43 \%$ higher yield over control with the harvest index of $25.95 \%$ whereas PU- $\mathrm{N}_{180}$ produced $246.93 \%$ higher yield over control with a harvest index of $23.37 \%$ (Table 5). It was observed that $29.5 \%$ higher yield was found from USG-N $\mathrm{N}_{160}$ as compared to PU-N 180 . USG-N 180 also produced more yield than that of PU-N ${ }_{180}$ which indicated the superiority of USG over PU. This result is in agreement with the findings of Greenwood et al. (1980) concerning the optimization of $\mathrm{N}$ dose to receive the maximum broccoli yield with the recommended doses from $175-252 \mathrm{~kg} \mathrm{~N} \mathrm{ha}^{-1}$. Goodlass et al. (1997) found that the most effective $\mathrm{N}$ rate in broccoli fertilization was $300 \mathrm{~kg} \mathrm{~N}^{-1}$. Zebarth $e t$ al. (1995) found that crop-marketable yield increased with increasing $\mathrm{N}$ rate in a curvilinear pattern. Chao-Jiong (2010) concluded that moderate N fertilization rate (200-300 $\left.\mathrm{kg} \mathrm{N} \mathrm{ha}^{-1}\right)$ could significantly increase the head size and maintain the storage life. The low crops, harvested from the control treatments are due to the insufficient supply of plants in $\mathrm{N}$, leading at first to 
limitation of carbon assimilation, resulting in reduction of plant productivity (Lawlor, 2002).

Table 5. Effect of different levels of USG and PU on yield and yield contributing characters of broccoli

\begin{tabular}{l|c|c|c|c}
\hline \multicolumn{1}{|c|}{ Treatment } & $\begin{array}{c}\text { Head dry weight } \\
\left(\mathrm{g} \text { plant }^{-1}\right)\end{array}$ & $\begin{array}{c}\text { Harvest index } \\
(\%)\end{array}$ & $\begin{array}{c}\text { Head yield } \\
\left(\text { ton ha }^{-1}\right)\end{array}$ & $\begin{array}{c}\text { Yield increased } \\
\text { over control (\%) }\end{array}$ \\
\hline Control & $21.74 \mathrm{c}$ & 24.25 & $4.88 \mathrm{~d}$ & - \\
USG-N $_{140}$ & $52.20 \mathrm{~b}$ & 23.21 & $11.72 \mathrm{c}$ & 240.16 \\
USG-N $_{160}$ & $60.12 \mathrm{a}$ & 25.95 & $13.49 \mathrm{a}$ & 276.43 \\
USG-N $_{180}$ & $57.59 \mathrm{ab}$ & 23.34 & $12.93 \mathrm{~b}$ & 264.50 \\
PU-N & $53.68 \mathrm{ab}$ & 23.37 & $12.05 \mathrm{c}$ & 246.93 \\
\hline $\mathrm{CV}(\%)$ & 6.88 & - & 6.88 & - \\
SE $( \pm 0.05)$ & 1.948 & - & 0.1693 & - \\
\hline
\end{tabular}

Means followed by uncommon letters are statistically different from each other at $5 \%$ level of provability by DMRT

Table 6. Effect of different levels of USG and PU on lateral head performance of broccoli

\begin{tabular}{|c|c|c|c|}
\hline Treatment & $\begin{array}{l}\text { Number of lateral head } \\
\text { plant }^{-1}\end{array}$ & $\begin{array}{l}\text { Lateral head weight } \\
\qquad\left(\mathrm{g} \text { plant }{ }^{-1}\right)\end{array}$ & $\begin{array}{l}\text { Lateral head yield } \\
\left.\qquad \text { (ton } \mathrm{ha}^{-1}\right)\end{array}$ \\
\hline Control & $2.913 \mathrm{c}$ & $50.60 \mathrm{~d}$ & $1.874 \mathrm{~d}$ \\
\hline USG-N 140 & $4.677 \mathrm{~b}$ & $84.28 \mathrm{c}$ & $3.121 \mathrm{c}$ \\
\hline $\mathrm{USG} \mathrm{N}_{160}$ & $5.103 \mathrm{ab}$ & $120.1 \mathrm{~b}$ & $4.449 \mathrm{~b}$ \\
\hline USG-N 180 & 5.380 a & 163.5 a & 6.054 a \\
\hline PU-N 180 & $5.040 \mathrm{ab}$ & $135.8 \mathrm{~b}$ & $5.030 \mathrm{~b}$ \\
\hline $\mathrm{CV}(\%)$ & 5.44 & 10.82 & 10.82 \\
\hline $\mathrm{SE}( \pm 0.05)$ & 0.1449 & 6.924 & 0.2563 \\
\hline
\end{tabular}

Means followed by uncommon letters are statistically different from each other at $5 \%$ level of provability by DMRT

\section{Number of lateral head}

Lateral head of broccoli was produced after harvesting of main head and it was influenced by the rate of $\mathrm{N}$ application. Different forms and levels of urea $\mathrm{N}$ on the performance of lateral head of broccoli was presented in Table 6. The highest number of lateral head (5.38) was recorded from USG-N $\mathrm{N}_{180}$ followed by USG$\mathrm{N}_{160}$ (5.103) which was statistically identical with PU-N $\mathrm{N}_{180}$ (5.04). It was clearly observed that the higher number of lateral head was formed with the application of N as USG form as compared to that of PU. The lowest number (2.913) was recorded from control. 


\section{Lateral head weight per plant}

Lateral head weight $\left(\mathrm{g} \mathrm{plant}^{-1}\right)$ was significantly influenced by the different form and levels of $\mathrm{N}$ fertilizer (Table 6)and it was increased with the increasing levels of $\mathrm{N}$. The maximum lateral head weight $\left(163.5 \mathrm{~g} \mathrm{plant}^{-1}\right)$ was recorded from USG-N $\mathrm{N}_{180}$ followed by PU-N $\mathrm{N}_{180}\left(135.8 \mathrm{~g}_{\text {plant }}{ }^{-1}\right)$ but significantly higher than all other treatment. The higher lateral head weight was observed in case of USG than that of PU. But the lowest lateral head yield $\left(50.60 \mathrm{~g}\right.$ plant $\left.^{-1}\right)$ was obtained from control.

\section{Lateral head yield}

Lateral head yield (ton ha ${ }^{-1}$ ) was significantly affected by the different forms and levels of $\mathrm{N}$ (Table 6) and more or less it was increased with the increasing levels of $\mathrm{N}$ application. The highest lateral head yield (6.054 ton $\left.\mathrm{ha}^{-1}\right)$ was achieved from the treatment USG-N $\mathrm{N}_{180}$ that was significantly higher than all other treatment. The second highest lateral head yield (5.030 ton ha-1) was recorded from PU-N ${ }_{180}$ that was statistically identical with USG-N ${ }_{160}$ (4.449 ton ha ${ }^{-1}$ ). From the data recorded, it was clearly observed that the higher lateral head yield was obtained with higher levels of N as USG than that of PU. The lowest lateral head yield $\left(1.874 \mathrm{t} \mathrm{ha}^{-1}\right)$ was obtained from the control.It indicated that nitrogen supply from USG had to be continued even after harvesting of main head which induced lateral head formation but it was not so in case of PU. After conducting experiment on broccoli Yoldas et al. (2008) found that $\mathrm{N}$ rates significantly increased yield, average weight of main and lateral heads, and the head diameter in broccoli compared to control with the highest total yield (34631 $\mathrm{kg} \mathrm{ha}^{-1}$ ) obtained from $300 \mathrm{~kg} \mathrm{~N} \mathrm{ha}^{-1}$. Similar result was reported by Hussain (2004) in broccoli cultivar Premium Crop.

Table 7. Partial budget analysis of broccoli as influenced by different levels of USG and PU

\begin{tabular}{|c|c|c|c|c|c|c|c|}
\hline $\begin{array}{l}\text { Treatment } \\
\text { combination }\end{array}$ & $\begin{array}{l}\text { Yield } \\
\left(\mathrm{t} \mathrm{ha}^{-1}\right)\end{array}$ & $\begin{array}{c}\text { Gross } \\
\text { return } \\
\left(\mathrm{Tk} \cdot \mathrm{ha}^{-1}\right)\end{array}$ & $\begin{array}{c}\text { TVC } \\
\left(\mathrm{Tk}^{-h^{-1}}{ }^{-1}\right)\end{array}$ & $\begin{array}{c}\text { Gross } \\
\text { margin } \\
\left(\mathrm{Tk}^{2} \mathrm{ha}^{-1}\right)\end{array}$ & $\begin{array}{c}\text { Added } \\
\text { return } \\
\left(\mathrm{Tk} \cdot \mathrm{ha}^{-1}\right)\end{array}$ & $\begin{array}{c}\text { Added } \\
\text { VC } \\
\left(\mathrm{Tk}^{-h^{-1}}\right)^{-}\end{array}$ & $\begin{array}{c}\text { MBCR } \\
\text { Over } \\
\text { control }\end{array}$ \\
\hline Control & 4.880 & 146400 & 105480.0 & 40920.0 & - & - & - \\
\hline USG-N 140 & 11.720 & 351600 & 115449.7 & 236150.3 & 205200 & 9969.7 & 20.58 \\
\hline USG-N 160 & 13.490 & 404700 & 116994.8 & 287705.2 & 258300 & 11514.8 & 22.43 \\
\hline USG-N ${ }_{180}$ & 12.930 & 387900 & 117846.9 & 270053.1 & 241500 & 12366.9 & 19.53 \\
\hline PU-N 180 & 12.050 & 361500 & 120351.6 & 241148.4 & 215100 & 14871.6 & 14.46 \\
\hline
\end{tabular}

Material cost: $\mathrm{PU}=\mathrm{Tk} .12 \mathrm{~kg}^{-1}$; USG $=\mathrm{Tk} .12 .50 \mathrm{~kg}^{-1} ;$ Labor $=\mathrm{Tk} .180 \mathrm{diam}^{-1}$; Placement cost (labor ha' $\left.{ }^{-1}\right)$ : For prilled urea: 56.58 labor (2 times) for $180 \mathrm{~kg} \mathrm{PU} \mathrm{ha}^{-1}$; For USG: 34.29 labor for $140 \mathrm{~kg}, 39.86$ labor for $160 \mathrm{~kg}, 41.58$ labor for $180 \mathrm{~kg} \mathrm{USG} \mathrm{ha}^{-1}$. Output cost: Broccoli price $=$ Tk. $30 \mathrm{~kg}^{-1}$ 


\section{Economic analyses and evaluation}

From the partial budget analysis it was found that the maximum gross return (Tk. $404700 \mathrm{ha}^{-1}$ ) was noted from the treatment USG-N 160 followed by USG-N 180 (TK. $387900 \mathrm{ha}^{-1}$ ) and USG-N ${ }_{140}$ gave the third highest gross return (TK. 361500 $\mathrm{ha}^{-1}$ ) with the gross margin of Tk. 287705.2, 270053.1 and 241148.4, respectively (Table 7). From this information the highest calculated MBCR (22.43) was obtained from USG-N $\mathrm{N}_{160}$ followed by USG-N $\mathrm{N}_{140}$ (20.58) and it was followed by USG-N $\mathrm{N}_{180}$ (19.53) which was higher as compared to that of PU-N $\mathrm{N}_{180}(14.46)$ over control.

Table 8. Partial budget analysis of broccoli as influenced by different levels of USG and PU

\begin{tabular}{|c|c|c|c|c|c|c|c|}
\hline $\begin{array}{l}\text { Treatment } \\
\text { combination }\end{array}$ & $\begin{array}{c}\text { Gross } \\
\text { return } \\
\left(\text { Tk. ha }^{-1}\right)\end{array}$ & $\begin{array}{c}\text { TVC } \\
\left(\text { Tk. ha }{ }^{-1}\right)\end{array}$ & BCR & $\begin{array}{c}\text { Gross } \\
\text { margin } \\
\left(\text { Tk. ha }^{-1}\right)\end{array}$ & $\begin{array}{c}\text { MGM } \\
\left(\text { Tk. ha }{ }^{-1}\right)\end{array}$ & $\begin{array}{c}\text { MVC } \\
\left(\text { Tk. ha }^{-1}\right)\end{array}$ & $\begin{array}{l}\text { MRR } \\
(\%)\end{array}$ \\
\hline Control & 146400 & 105480.0 & 1.39 & 40920.0 & - & - & - \\
\hline $\mathrm{USG} \mathrm{N}_{140}$ & 351600 & 115449.7 & 3.05 & 236150.3 & 195230.3 & 9969.7 & 1958.24 \\
\hline USG-N $\mathrm{N}_{160}$ & 404700 & 116994.8 & 3.46 & 287705.2 & 51554.9 & 1545.1 & 3336.67 \\
\hline USG-N $_{180}$ & 387900 & 117846.9 & 3.29 & 270053.1 & -17652.1 & 852.1 & $\mathrm{D}$ \\
\hline PU-N 180 & 361500 & 120351.6 & 3.00 & 241148.4 & -28904.7 & 2504.7 & D \\
\hline
\end{tabular}

Material cost: $\mathrm{PU}=\mathrm{Tk} .12 \mathrm{~kg}^{-1} ; \mathrm{USG}=\mathrm{Tk} .12 .50 \mathrm{~kg}^{-1} ; \mathrm{Labor}=\mathrm{Tk} .180 \mathrm{diam}^{-1} ;$ Placement cost (labor ha' $\left.\mathbf{h a}^{-1}\right)$ : For prilled urea: 56.58 labor (2 times) for $180 \mathrm{~kg} \mathrm{PU} \mathrm{ha}^{-1}$; For USG: 34.29 labor for $140 \mathrm{~kg}, 39.86$ labor for $160 \mathrm{~kg}, 41.58$ labor for $180 \mathrm{~kg} \mathrm{USG} \mathrm{ha}^{-1}$. Output cost: Broccoli price $=$ Tk. $30 \mathrm{~kg}^{-1}$

From Table 8, it was found that maximum BCR (3.46) and highest MRR $(3336.67 \%)$ was obtained from $\mathrm{USG}_{160}$ followed by $\mathrm{USG}_{140}$ which indicated that $\mathrm{USG}_{160}$ is the most economically viable $\mathrm{N}$ dose in terms of yield and economics for broccoli production. Similar findings was reported by Talukder et al.(2004) in tomato; Rahman et al. (2004) in potato; Nazrul et al. (2007) and Sarkeret al. (2012) in cabbagethose indicate the superiority of USG over existing PU practice.

\section{Conclusion}

Based on the above discussions it may be concluded that USG @ 160kg N ha ${ }^{1}$ is the superior form and rate of $\mathrm{N}$ application getting a good desirable and economic yield of broccoli.Higher number of lateral head (5.38) and lateral head yield (6.054ton $\mathrm{ha}^{-1}$ ) was produced by USGin comparison to PU. Head compactness was significantly increased with increasing levels of $\mathrm{N}$ but it isstatistically identical forboth USG and PU. From economic viewpoint USG @ $160 \mathrm{~kg} \mathrm{~N} \mathrm{ha}^{-1}\left(\mathrm{USG}-\mathrm{N}_{160}\right)$ showed the maximum economic profitability in 
terms of both MBCR (22.43) and MRR (3336.67\%). Therefore, USG @ 160 $\mathrm{kg} \mathrm{N} \mathrm{ha}^{-1}$ (USG-N ${ }_{160}$ )with other recommended fertilizer could be suggested as an USG based fertilizer recommendation for broccoli production in terms of yield and economic profitabilityat Salna series soil of BSMRAU in Madhupur Tract.

\section{References}

Babik, I. andK. Elkner. 2002. The effect of nitrogen fertilization and irrigation on yield and quality of broccoli. Acta Horticulture. 571: 33-43.

Balyan, D. S.,B. S. Dhankar, D. S. Ruhal and K. P. Singh. 1988. Growth and yield of cauliflower variety Snowball-16 as influenced by nitrogen, phosphorus and zinc. Haryana Journal of Horticultural Science. 17: 247-254.

Castellanos, J.,Z. I. Lazcano, A. Sosa Baldibia, V. Badillo andS. Villalobos. 1999. Nitrogen fertilization and plant nutrient status monitoring - the basis for high yields and quality of broccoli in potassium-rich vertisols of Central Mexico. Better Crops International. 13(2): 25-27.

Chao-Jiong Xu, Rong-Fang Guo, Hui-Zhuan Yan, Jing Yuan, Bo Sun, Gao-Feng Yuan and Qiao-Mei Wang. 2010. Effect of nitrogen fertilization on ascorbic acid, glucoraphanin content and quinine reductase activity in broccoli floret and stem. Journal of Food, Agriculture \& Environment. 8 (1): 179-184.

Defalt, R. J. 1988. Nitrogen and phosphorous requirements for green house broccoli production. Hort. Sci. 23 (3):576-578.

Everaarts, A. P.and P. de Willigen. 1999. The effect of the rate and method of nitrogen application on nitrogen uptake and utilization by broccoli (Brassica oleraceavar.Italica). Netherlands Journal of Agricultural Science. 47:201-214.

Fahey, J., W. X. Haristoy, P. M. Dolan, T. W. Kensler, I. Scholtus, K. K. Stephenson, P. Talalay, and A. Lozniewski. 2002. Sulforaphane inhibits extracellular, intracellular and antibiotic-resistant strains of Helicobacter pylori and prevents benzo[a]pyreneinduced stomach tumors. Proceedings of the National Academy of Sciences of the United States of America. 99 (11): 7610-7615.

FAO, 1988. Production year book. Food and Agricultural Organization. Rome, Pp. 157-158.

Goodlass, G.,C. Rahn,M. A. Shepherd, A. G. Chalmers andF. M. Seeney. 1997. The nitrogen requirement of vegetables: comparisons of yield response models and recommendation systems. J. Hort. Sci. 72(2): 239-254.

Greenwood, D. J.,T. J. Cleaver, M. K. Turner, J. Hunt, K. B. Niendorf andS. M. H. Loquens. 1980. Comparison of the effects of nitrogen fertilizer on the yield, nitrogen content and quality of 21 different vegetable and agricultural crops. Journal of Agricultural Science. 95: 471-585.

Hala Kandil and Nadia Gad. 2009. Effects of inorganic and organic fertilizers on growth and production of broccoli (Brassica oleracea L.). Factori şi Procese Pedogenetice din Zona Temperată S. Nouă.8: 61-69. 
Hussain, M. J.,M. Y. Ali, M. A. Rahman, M. A. Helim Khan and M. M. Rahman. 2003. Application of urea super granule (USG) in vegetable crops: a profitable technology. Bangladesh Agricultural Research Institute and SFFP, Department of Agricultural Extension. Pp. 1-10.

Hussain, Md. 2004. Effect of nitrogen and boron on the yield and hollow stem disorder of broccoli. M. S. Thesis, Dept. Soil Science, Bangabandhu Sheikh Mujibur Rahman Agricultural University Gazipur.

Lawlor, D.W. 2002. Carbon and nitrogen assimilation in relation to yield: mechanisms are the key to understanding production systems. Journal of Experimental Botany. 53(370): 773-787.

Liu, L.,B. J. Shelp and G. A. Spiers. 1993. Boron distribution and translocation in fieldgrown broccoli (Brassica oleracea var. Italica). Canadian Journal of Plant Science. 73: $587-600$.

Nazrul, M.I.,M. J. Hussain, M.Y. Ali and R.U. Shahmim. 2006. Use of urea super granule (USG) in vegetables cultivation: A profitable technology (Booklet). Published by Bangladesh Agricultural Research Institute, Gazipur. 8 P.

Nazrul, M. I.,M. A. Rahman, D. A. Choudhury and M. A. Quayyum. 2007. Effect of different time and depths of USG application on growth and yield of cabbage. Bangladesh Journal of Agricultural Research. 32(2): 301-306.

Ouda, B. A. and A.Y. Mahadeen. 2008. Effect of fertilizers on growth, yield, yield components, quality and certain nutrient contents in broccoli (Brassica oleracea). International Journal of Agriculture \& Biology. 10(6): 627-32

Perrin, P. K.,D. L.Winkelman, E. R. Moseardi and J. R. Anderson. 1979. Farm agronomic data for farmer's recommendation. Information bulletin 27. CIMMYT, Mexico.

Rahman, M. A.,M. H. Akand, M. M. Rahman and M. Y. Ali. 2004. Effect of urea super granule and prilled urea application on agro-economic performance of potato. Journal of Agricultural Education Technology. 6(1\&2): 17-20.

Renata Wojciechowska, Stanisław RoŜek, Agata Rydz. 2005. Broccoli yield and its quality in spring growing cycle as dependent on nitrogen fertilization. Folia Horticulturae Ann. 17 (2) :141-152.

Rickard Mellgren. 2008. Effect of irrigation and nitrogen treatments on yield, quality, plant nitrogen uptake and soil nitrogen status and the evaluation of sap test, SPAD chlorophyll meter and Dualex to monitor nitrogen status in broccoli. Master thesis in the Horticultural Science Programme. 2008:4 45 hp.

Sarker, M. M. R., M. R. Shaheband M. I. Nazrul. 2012. Urea Super Granule: A good source of nitrogen on growth yield and profitability of cabbage in Sylhet. Journal of Environmental Science and Natural Resources. 5(1): 295-299.

Talukder M. A. H.,M. A. Mannaf, S. M. A. Jabber, M. B. Islam, S. M. A. H. M. Kamal and A. K. Saha. 2004. Effect of urea super granule as a source of nitrogen on the growth and yield of tomato. Pakistan journal of Biological sciences. 7(12):20782081. 
Thakur, O. P.,P. P. Sharma and K. K. Singh. 1991. Effect of nitrogen and phosphorus with and without boron on curd yield and stalk rot incidence in cauliflower. Vegetable Science. 18(2): 115-121.

Thomson, H.C. and W. C. Kelly.1985. Vegetable crops. 5th edition, Mengrow Hill Book Co. p 18:280-281.

Yoldas, F.,S. Ceylan, B. Yagmur and N. Mordogan. 2008. Effect of nitrogen fertilizer on yield quality and nutrient content in broccoli. Journal of Plant Nutrition. 31: 13331343.

Zaman, S. K.,M. A. Razzaque, S. M. R. Karim and A. U. Ahmed. 1993. Evaluation of prilled urea and urea super granule as nitrogen sources for upland aus rice. Bangladesh Rice Journal. 4: 42-46.

Zebarth, B. J.,P. A. Bowen and P. M. A. Toivonen. 1995. Influence of nitrogen fertilization on broccoli yield, nitrogen accumulation and apparent fertilizer-nitrogen recovery. Canadian Journal of Plant Science. 75(3): 717-725. 
